\title{
Butterfly as bioindicator for development of conservation areas in Bukit Reban Kambing, Bukit Belading and Bukit Tukau, Johor, Malaysia
}

\author{
NORRADIHAH ISMAIL ${ }^{1}$, AQILAH AWG ABDUL RAHMAN ${ }^{1}$, MARYATI MOHAMED ${ }^{1, \bullet}$, \\ MOHD FADZELLY ABU BAKAR ${ }^{1}$, LILI TOKIMAN ${ }^{2}$ \\ ${ }^{1}$ Centre of Research for Sustainable Uses of Natural Resources (CoR-SUNR), Faculty of Applied Sciences and Technology, Universiti Tun Hussein Onn \\ Malaysia, Campus Pagoh, KM 1, Jalan Panchor, 84000 Muar, Johor, Malaysia. `email: maryatihayati52@ gmail.com \\ ${ }^{2}$ Johor National Parks Corporation, Level 1, Dato’ Mohamad Salleh Perang Building, Kota Iskandar, 79100, Nusajaya, Johor, Malaysia
}

Manuscript received: 6 November 2019. Revision accepted: 29 December 2019.

\begin{abstract}
Ismail N, Rahman A A A, Mohamed M, Abu Bakar M F, Tokiman L. 2020. Butterfly as bioindicator for development of conservation areas in Bukit Reban Kambing, Bukit Belading and Bukit Tukau, Johor, Malaysia. Biodiversitas 21: 334-344. Butterflies are often used as indicator surrogates to evaluate the quality of ecosystems. This is made possible due to their sensitive responses toward environmental fluctuations and habitat changes. Butterflies were collected opportunistically using aerial nets at three hill dipterocarp forests; Bukit Reban Kambing (BRK), Bukit Belading (BB) and Bukit Tukau (BT) of Johor, Malaysia from $8^{\text {th }}$ to $11^{\text {th }}$ March 2016 . The objectives of this study are to provide a checklist of butterflies of the hills and evaluate habitat suitability in an effort to support the proposal to gazette the hills as part of the Gunung Ledang protected area. A total of 60 individuals belonging to 23 species, 21 genera, and five families were recorded. Comparing the three hills, BRK recorded the greatest individual and species numbers, followed by BT and BB. BRK recorded the highest Shannon diversity index, H' (2.272) value, whereas BB presented the highest value of species evenness index, E' (0.945). MaxEnt modeling of the butterflies in BRK, BB, and BT showed a network of high habitat suitability areas connecting Gunung Ledang and our sampling locations. Despite limited sampling effort, this baseline data could possibly strengthen the effort for gazettement and prevent further pressure from mining activity and land conversion.
\end{abstract}

Keywords: Butterfly, gazettement, hills, habitat suitability

\section{INTRODUCTION}

One of the uses of rapid biodiversity assessment (RBA) is to collect the baseline inventories such as species list, community structure (diversity and distribution pattern) and significant species for conservation (protected and endemic species) of that particular area using the indicator surrogates (Gopal 2015). This RBA data could then be used to indicate the overall biodiversity of the site, reflecting the health of the current environmental condition there. Butterflies are often used as monitoring tools to value the biodiversity of forests and ecosystem functions due to their sensitive responses toward environmental fluctuations and habitat changes (Gerlach et al. 2015). Apart from that, they are highly diverse, easy to identify, suitable for quantitative sampling, could be found in many habitat and indicators for endemism (Foottit and Adler 2009). Many reports showed that the richness, abundance, and distribution of butterfly communities were greatly affected by the different land uses (Nkongolo and Bapeamoni 2018), seasonal changes (Hill et al. 2003; Ramesh et al. 2013), forest fragmentation ( $\mathrm{Vu}$ and $\mathrm{Vu}$ 2011), forest disturbance (Lien and Yuan 2003), forest types (Widhiono 2015) and human activities such as logging (Cleary et al. 2005; Hamer et al. 2005) and mining (Kyerematen et al. 2018).

Therefore, a Johor Nature Heritage Expedition 2016 was held for five consecutive days from 7 till 12 March
2016 and organized by Johor National Parks Corporation (JNPC). The expedition covered the areas of Bukit Tukau (BT), Bukit Belading (BB) and Bukit Reban Kambing (BRK) at Ledang district with a total area of 320.21 ha. Besides act as important water catchment for Tangkak district of Johor state and Asahan of Malacca, the areas are also habitat for an endemic and critically endangered cycad species, Cycas cantafolia Jutta, K.L. Chew \& Saw (Jutta et al. 2010) and also a newly described and critically endangered flowering plant, Senyumia granitica (Kiew and Lau 2019). These areas, however, are located outside the network of Totally Protected Area and severely threatened by the presence of mining and agricultural activities (Kiew and Lau 2019). Thus, this expedition aimed to inventory flora and fauna including orchids, tree flora, macrofungi, ants, odonates, termites, fish, anurans and rocks to support the proposal to gazette the three hills as part of Gunung Ledang National Park (BERNAMA 2016).

Particularly, this study was conducted; (i) to assess the biodiversity of the three hills specifically the butterfly communities, in turn providing a baseline data of butterfly diversity for those hills, (ii) to evaluate habitat suitability for wildlife and (iii) to update the checklist of butterfly fauna in Gunung Ledang and its vicinity. Then, this RBA data could support and strengthen the gazettement of those areas. 


\section{MATERIALS AND METHODS}

\section{Study area}

This study was conducted at three different hill dipterocarp forests consists of Bukit Reban Kambing (BRK, N 02²0.11'; E 102 $32.50^{\prime}$ ), Bukit Belading (BB, N $02^{\circ} 19.32^{\prime} ;$ E $102^{\circ} 31.59^{\prime}$ ) and Bukit Tukau (BT, N $\left.02^{\circ} 18.634^{\prime} ; \mathrm{E} 102^{\circ} 32.217^{\prime}\right)$. The elevations range of the areas between 118 to $515 \mathrm{~m}$ a.s.l. The areas are adjacent to Gunung Ledang, one of the national parks in Johor and indigenous settlement (Figure 1). The forest areas are fragmented by the agricultural areas such as orchard, oil palm and rubber plantations. An active quarry is also located at the foot of BB and BT. In fact, the area of BT had been logged as dominated by few big trees and other common plants such as bamboo (Dinochloa sp. and Gigantochloa ligulata), rattan (Daemonorops sp.), palm (Arenga westerhoutii) and Pandanus sp. (Lau and Saw 2010; Kiew and Lau 2019). Based on finding from Johor Nature Heritage Expedition 2016, a total of 155 tree species belonging to 108 genera and 50 families were recorded from those hill forests, which comprising the largest family (Annonaceae), vulnerable species (Anisoptera laevis, Dipterocarpus fagineus and Aquilaria malaccensis) and endemic species (Cyathocalyx pruniferus, Dacryodes longifolia, Diospyros argentea, D. nutans, Syzygium politum and Gordonia concentricicatrix) (Lau et al. 2017). The uniqueness of BRK and BT came from metamorphic rock which originated from Gemas formation and the rock dated at least 200 million years ago, meanwhile, the granitic covers the area of BB (Madun et al. 2017).

\section{Data collection}

Butterflies were sampled opportunistically along the tracking trails of each hill forests between 09: 00 to 17: 00 . The collection was conducted manually using aerial nets with two-man efforts. All butterfly specimens were identified using keys and illustrations in Fleming (1975), Corbet and Pendlebury (1992) and Kirton (2014).

\section{Data analysis}

The data were analyzed to determine the biodiversity values in terms of species richness, species abundance, species diversity and pattern of distribution at each forest hills. Several indices were used such as Shannon diversity index $\left(\mathrm{H}^{\prime}\right)$ to describe diversity of butterfly, species evenness index (E') to determine species distribution pattern and Jaccard similarity index (J) to describe the similarity of butterfly species occurred at those three hills (Magurran 2004; Magurran and McGill 2011). Also, the composition of butterfly communities was assessed based on species accumulation curve and rank abundance curve. Overall, the species richness estimation of butterfly fauna in Gunung Ledang was measured based on incidence data, using nonparametric estimators such as first-order Jackknife (Jack1), second-order Jackknife (Jack2), Chao2 and ICE.

\section{Species distribution modeling}

The potential distribution of the butterflies in the vicinity of $\mathrm{BB}, \mathrm{BRK}$, and $\mathrm{BT}$ were determined using MaxEnt (Phillips et al. 2006). MaxEnt is a modeling method that has gained traction in popularity over recent years due to its simplicity, reliability and user-friendly interface (Elith et al. 2011). It estimates the density of occurrence of a species across an environmental space. In this study, the model used distribution data of butterflies obtained from this study and other inventory works in Johor. The variables used include distance to forest, temperature fluctuations, precipitation and distance to road. A plot of suitable habitat with values ranging from 0 to 1 was produced by the model. A value close to 0 indicates low habitat suitability, while a value close to 1 indicates high habitat suitability. Further description of the methods and data used in this study can be obtained from Aqilah (2019).
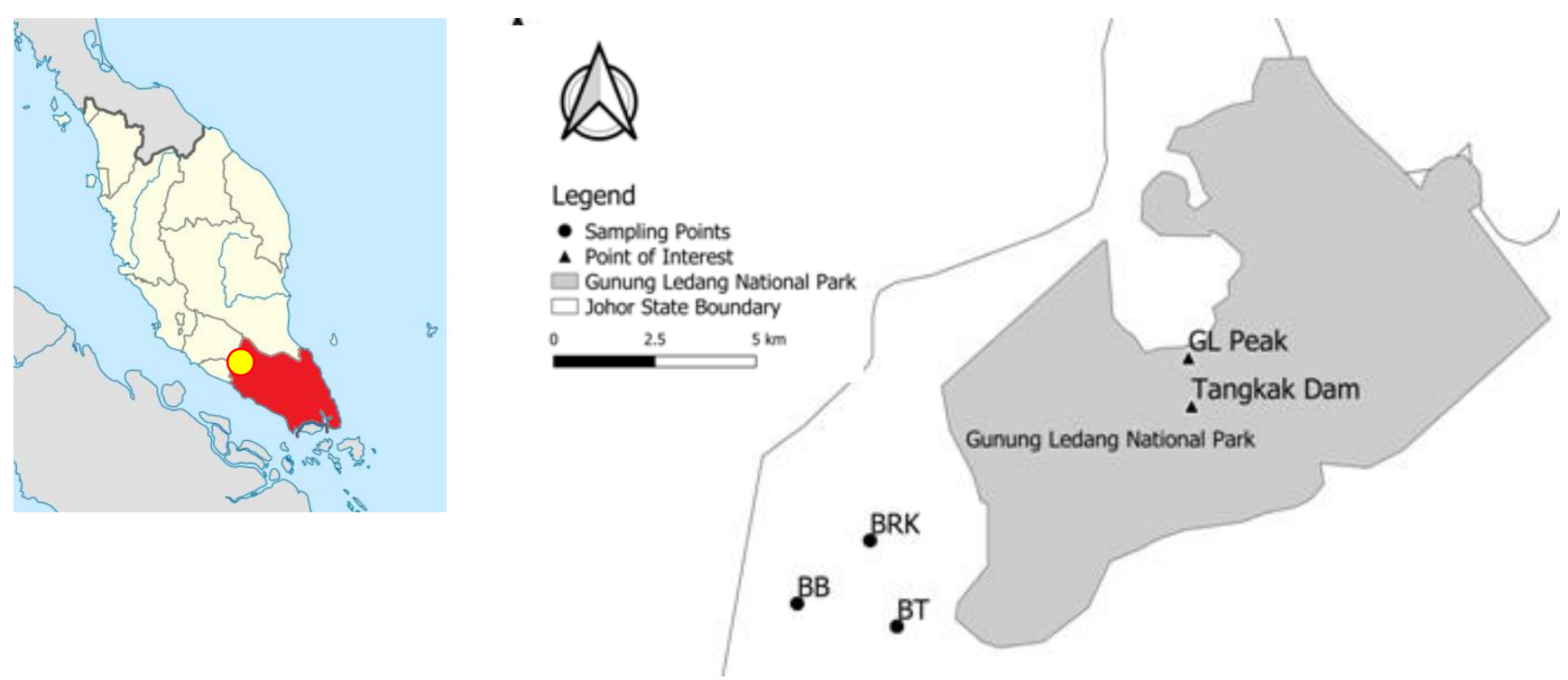

Figure 1. Map of sampling location at Bukit Reban Kambing (BRK), Bukit Belading (BB) and Bukit Tukau (BT) in Johor, Malaysia 


\section{RESULTS AND DISCUSSION}

\section{Species composition and diversity of butterfly}

A total of 60 individuals belonging to 23 species in 21 genera representing five families were recorded during four days sampling period (as listed in Table S1). This included two protected species under Wildlife Conservation Act 2010 [Act 716], which are Charaxes bernardus crepax Fruhstorfer (Figure 4.D) and Charaxes durnfordi durnfordi Distant (Figure 4.E)

Overall, Nymphalidae was the most speciose (12 species) and abundant (38\%) family. Followed by Pieridae (4 species; $35 \%$ of individuals), Lycaenidae $(3 ; 10 \%)$ and Hesperiidae (3; 5\%). Lastly, Papilionidae being the least diverse family $(1 ; 6.7 \%)$ (Figure 2). Family composition reported in Bukit Soga (Aqilah et al. 2018) also showed similar distribution patterns. The collections were dominated by nymphalids as they are known as the most varied family with the largest subfamilies (Corbet and Pendlebury 1992). In fact, they are easily found as they are active fliers and polyphagous. Thus, enable them to forage into larger area and inhabit in different forest ecosystems (Abang and Fauzi 2004). On the other hand, papilionids are the least presented and difficult to capture in flight as they are large, strong fliers and typically hovering higher (Kirton 2014).

Overall, the Shannon diversity index $\left(\mathrm{H}^{\prime}\right)$ indicated only 2.698 and species evenness index (E') was 0.646. In fact, the species richness and diversity recorded in this study were moderate as considering the limited sampling period, area and method covered. Species recorded in this study was relatively low when compared to collections from other parts of Malaysia such as Gunung Ledang (129 species, $H^{\prime}=3.405$; Ismail et al. 2018), Gunung Kuli (51 sp., H'= 3.83; Sulaiman et al. 2010) and Bukit Soga (43 sp., $H^{\prime}=4.78$; Aqilah et al. 2018). However, substantially comparable with figures recorded for other hill forests such as Fraser's Hill (32 species; Ghazali et al. 2018) and Cameron Highlands (11 sp., Aris et al. 2017). The fragmentation and disturbance of these forests due to agricultural (oil palm plantation and small scale orchard) and quarry activities could affect the butterfly assemblages especially butterfly species which has poor dispersal ability and habitat specialization (Mattila et al. 2011). The isolated forests of BRK, BB, and BT surrounded by non-forest habitat would restrict the movement of butterflies especially forest-dependent species as the larval food sources are largely the forest herbs and trees (Scriven et al. 2017).

\section{Butterfly ecology in relation to different hill forests}

Based on Table 1, it shows that BRK was found to be the richest and most abundant, followed by BT and BT. The diversity index, H' also showed the same pattern, highest at BRK and least at BB. In contrast, BB presented much higher value of evenness index, E' than BRK, which indicating more even species distribution patterns. Though low diversity was expected in $\mathrm{BB}$ since this area was a disturbed forest and affected by the nearby quarry, each butterfly species was occurring here in equal proportion in term number of individuals.

Among three hills, the butterfly assemblages of BRK and BT were more similar, recording the highest similarity index, Jaccard (17.4\%), followed by comparison between BB and BT (16.7\%) and the least similar between BRK and BB, only $10.5 \%$. While only two species such as Papilio iswara iswara White and Delias hyparete metarete Butler (Figure 4.A) were common in all three hills, there are 11 species only found in BRK, four species in BT and two species were recorded only from BB. However, BRK and BT shared four same species including Cyrestis cocles earli Distant (Figure 4.G), Hypolimnas bolina jacintha (Drury) (Figure 4.B), C. bernardus crepax and Jamides bochus nabonassar (Fruhstorfer).

The differences in species richness and abundance between hills suggest that vegetation types, environmental conditions, host plant resources, and disturbance are most likely to influence the butterfly population and distribution. BRK is located at the forest edge, which is adjacent to orchards and plantations could provide more food sources and host plants (banana, lime and oil palm trees). The forest edge has a butterfly assemblage consisting of both forest species and open species that result in high number of butterfly species and abundance recorded ( $\mathrm{Vu}$ 2009). Meanwhile, the condition of BB was too dry due to active quarry activities nearby and the rock formation comprising granite rock that mostly porous and coarse could result in habitat deterioration, in turn naturally affect butterfly population. The extreme forest disturbance and environmental conditions are likely to result in loss of many species (Bonebrake et al. 2016). Despite those conditions and disturbance, a few coupled pairs of butterflies were observed in flight especially at denser forest areas of BRK and BT during the survey. It shows that the vegetation in those areas is still able to support butterfly food sources.

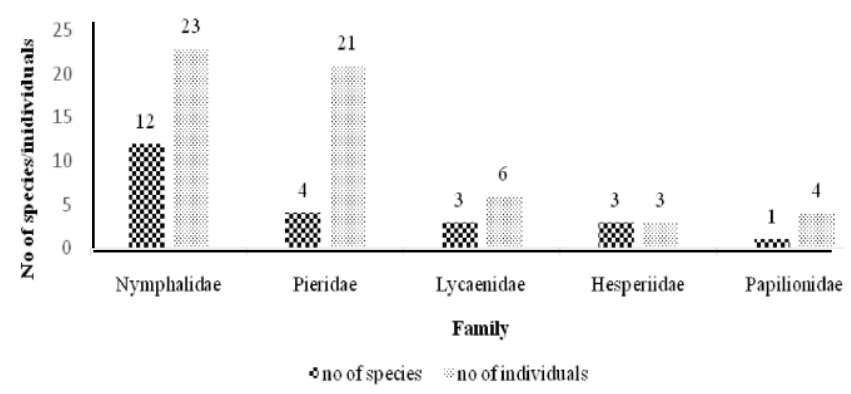

Figure 2. Species composition according to families at BRK, BB and BT in Johor, Malaysia

Table 1. Quantitative index of butterfly species diversity at three hill forests

\begin{tabular}{llll}
\hline & BRK & BB & BT \\
\hline No of species & 17 & 4 & 10 \\
No of individuals & 38 & 6 & 16 \\
Shannon diversity index, H' & 2.272 & 1.33 & 2.155 \\
Species evenness index, E' & 0.5705 & 0.9449 & 0.8625 \\
\hline
\end{tabular}




\section{Distribution pattern of butterfly communities}

Rank abundance in Figure 3 was used to rank species by abundance, then, could identify commonness and rarity of the species (Magurran and Henderson 2011). The most abundant butterfly recorded was Leptosia nina nina (Fabricius) (Figure 4.C) with 15 individuals and generally found at open, grassy patch and orchard areas at the foot of BRK. This common species is easily seen flying low at the forest clearing, forest edges and parks from lowland to moderate elevations (Kirton, 2014). Mostly the larvae feed on the cultivated plants (Corbet and Pendlebury 1992) and herbaceous weed (Cleome rutidosperma DC. as abundantly found at the foot of BRK) (Butterfly Circle 2019). Followed by $H$. bolina jacintha (6) and $C$. bernardus crepax (6). They were easily sighted in flight as coupled pairs at the forest areas of BRK and BT, mostly at the opening area in the canopy.

The species represented by small number of individuals occurring in the study area could impart the impression of rarity of a species (Abu Zarim and Ahmad 2014). During this study, the butterfly collection was mainly reported by singletons, which accounts for $61 \%$ (14 species). The species are Ideopsis gaura perakana Fruhstorfer (Figure 4.F), Euploea sylvester harrisii C. \& R. Felder, Junonia orithya wallacei Distant and Plastingia naga (de Niceville)
(Figure 4.I). However, the singleton species are quite prevalent in insect assemblages especially in the tropics (Hamer et al. 2005). For example, 34\% of singletons species of butterflies also were reported in a lowland dipterocarp rainforest in New Britain (Miller et al. 2011). Therefore, prevalence of singleton specimens could be related by low sampling intensity, sampling time, environmental condition and some species might appear occasionally contributing to low abundance (Magurran and McGill 2011).

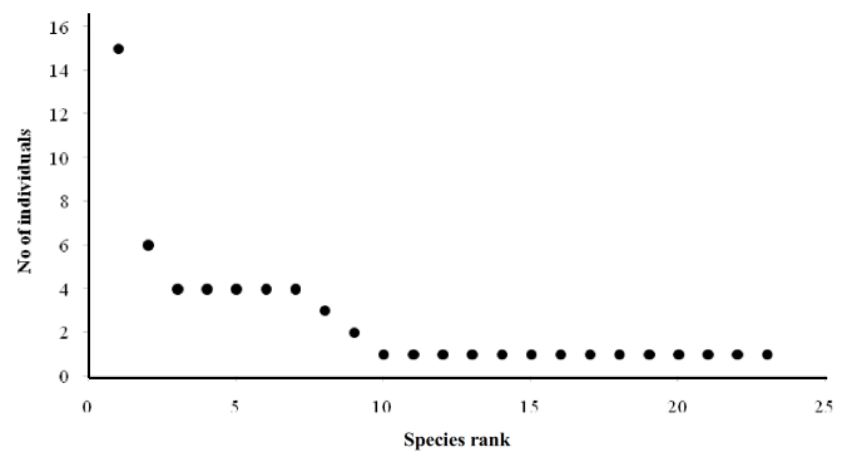

Figure 3. Rank abundance curve of butterfly at BRK, BB, and BT in Johor, Malaysia

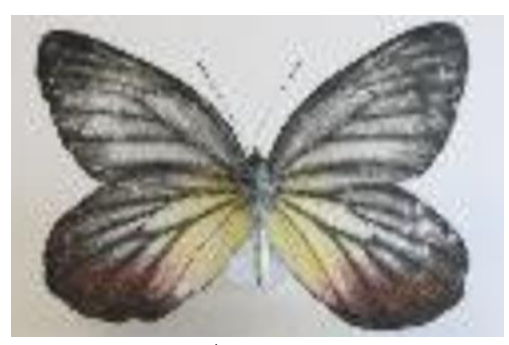

A

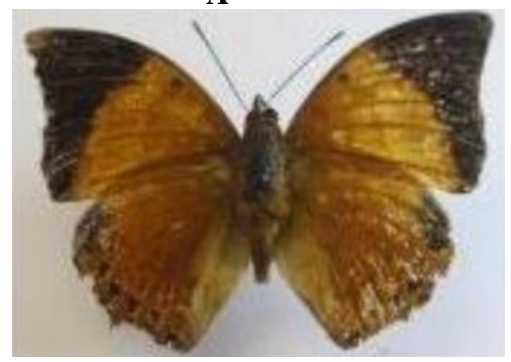

D

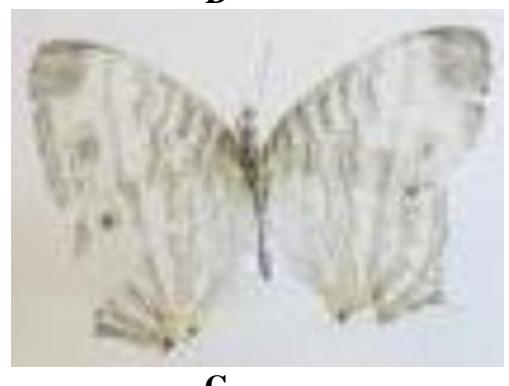

G

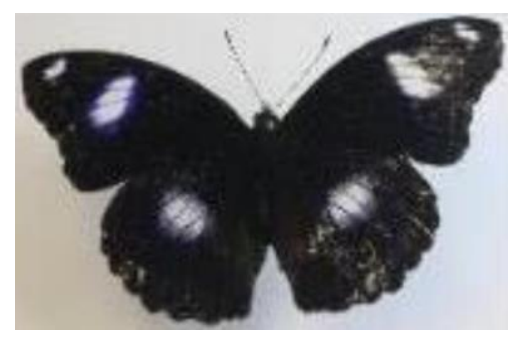

B

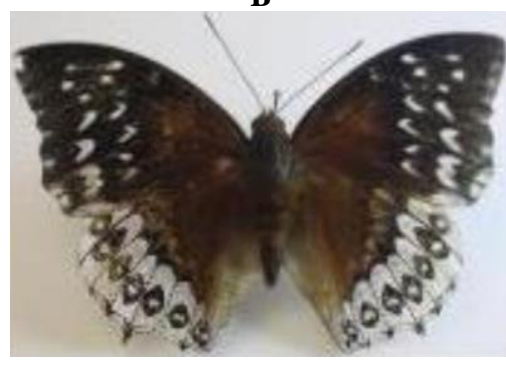

$\mathbf{E}$

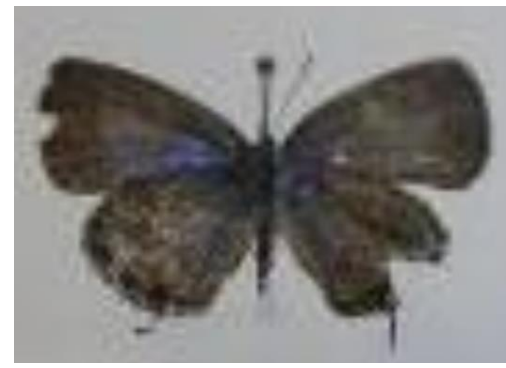

$\mathbf{H}$

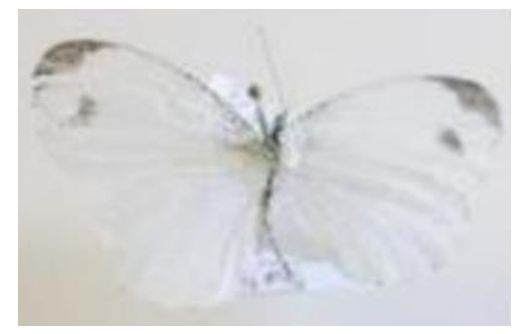

C

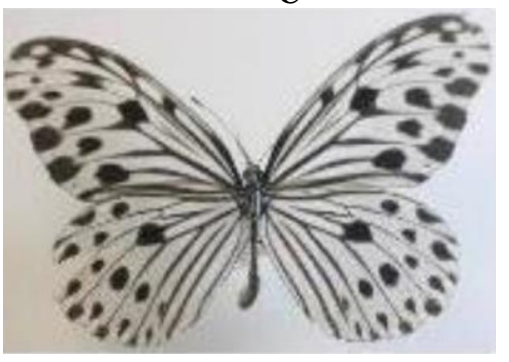

$\mathbf{F}$

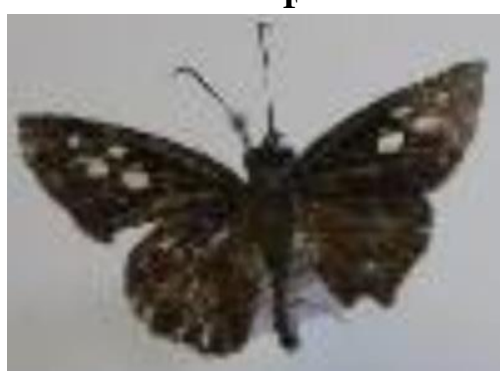

I

Figure 4. Some butterfly species were collected in the three hill forests at BRK, BB, and BT in Johor, Malaysia. A. Delias hyparete metarete Butler, B. Hypolimnas bolina jacintha Drury, C. Leptosia nina nina (Fabricius), D. Charaxes bernardus crepax Fruhstorfer, E. Charaxes durnfordi durnfordi Distant, F. Ideopsis gaura perakana Fruhstorfer, G. Cyrestis cocles earli Distant, H. Chilades pandava pandava Horsfield, I. Plastingia naga de Nicéville 


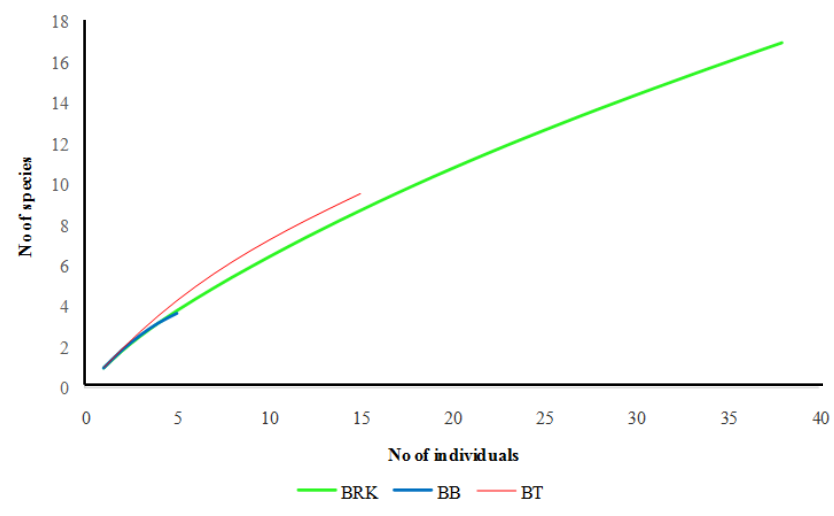

Figure 5. Species accumulation of butterfly species at BRK, BB, and BT in Johor, Malaysia

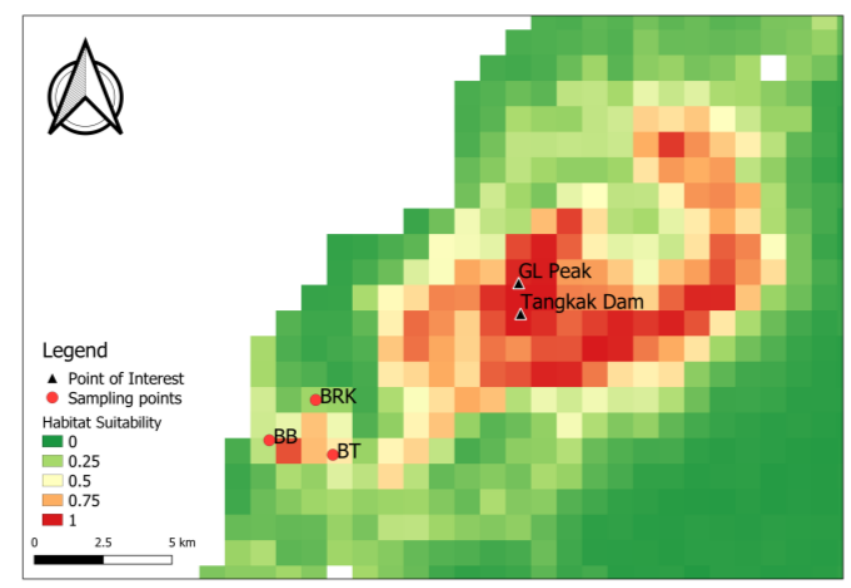

Figure 6. Species distribution modeling map of butterflies in BRK, BB and BT using MaxEnt

Butterfly communities are expected to discover more species if the sampling efforts continue as the curves of species accumulation graph are still steeply increasing and not reaching an asymptote in neither of those three hills (Figure 5).

Based on habitat and distribution, this study significantly recorded about 14 forest species, whereas nine are considered as common species (Kirton 2014; Corbet and Pendlebury 1992). In general, both forest and common or generalist species were captured, indicating the availability of food sources, changes in vegetation structure and level of disturbance in these forests. The overall assemblage of butterfly species also could allow evaluating the habitat quality in these forests. Higher number of forest species recorded might indicate the forest resources and plant diversity are still diverse and able to support more forest-dependent butterfly species (Joshi and Arya 2007).

\section{Notable and indicator species}

Another species encountered in this study was the Cycad Blue, Chilades pandava pandava Horsfield (Figure 4.H), which was found associated with cycad tree, Cycas cantaforlia at the peak of BRK. This species has become a pest for cycad and Sago palm trees as the caterpillars feed on the young leaves or soft tissues ( $\mathrm{Li}$ et al. 2010). In terms of conservation status, three nymphalids including $C$. durnfordi, C. bernardus, and Cyrestis cocles earli Distant are considered rare. According to Fleming (1975), Corbet and Pendlebury (1992) and Kirton (2014), they are known as uncommon species due to their secretive habit, wellcamouflage and localizing in forested area or dense forest. Meanwhile, two species namely $C$. bernardus and $C$. Durnfordi also protected under Malaysia's Wildlife Protected Species Act 2010 [ACT 716] (Wildlife Conservation Act 2010). The presence of these notable species in BRK and BT would develop strong support for the implementation of those areas as protected forest.

\section{Species distribution modeling}

A map was generated based on the plot developed by the MaxEnt model used in this study (Figure 6). The warmer color in the map represents higher habitat suitability, while the opposite color signifies lower habitat suitability. The map shows that the warmer color forms a network between Gunung Ledang, BRK, BB, and BT. This further proves that Gunung Ledang, BRK, BB, and BT is an interconnected ecosystem suitable for wildlife habitats such as butterflies. A similar case that involves a network of important conservation areas that are partially gazetted can be seen in Ulu Jelai Forest Reserve and Taman Negara National Park (Mohd Taher et al. 2018). Their modeling results show that both forests, which are located next to each other, have high habitat suitability for Tragulus napu, the Greater Mouse Deer. This further stresses the need to connect any forests that are located close to each other to form a greater network of natural habitat for its wildlife. In this study, the areas in green are deemed unsuitable due to several reasons. This may be due to the location being oil palm plantations, surrounded by roads and unsuitable overall temperature and precipitation. This shows that the forest butterfly species within the vicinity of BRK, BB and BT and confined to the forested areas in the area. An effort to gazette this area as part of Gunung Ledang protected area would be one of the best options to conserve the valuable natural resources and guarantee a bigger area for the wildlife to roam and thrive.

\section{Updating checklist of butterflies in Gunung Ledang}

The butterfly collections were periodically conducted at several vicinities of Gunung Ledang from 2012 to 2019. The collection areas included Gunung Ledang Johor National Park, covering two transects; Lagenda and Empangan trails (Maryati et al. 2014; Siddiki, 2015; Ismail et al. 2018) as well as Gunung Ledang Resort (Aqilah 2019; on-going surveyed by Hasnizan (2019)). Meanwhile, this study was shortly surveyed at three hills including BT, BRK, and BB during scientific expedition in 2016. Overall, the current number of species recorded in Gunung Ledang and its vicinity is 178 species, representing $17 \%$ of the total butterfly fauna in Peninsular Malaysia (1038 sp.; Eliot and Kirton 2000). Species recorded in Gunung Ledang are 
comparable with other highland forests in Malaysia such as Gunung Stong (146 species, Zaidi et al. 2005), Gunung Serambu (97 species, Pang et al. 2016) and Gunung Panti (83 species, Sulaiman et al. 2009), but substantially less than Gunung Tahan (248 species, Kirton et al. 1990) and Gunung Mulu (276 species, Hazebroek and Morshidi 2006).

The species cumulative graph shows the trend of butterfly species discovery from 2012 to 2019 still increasing and continuous addition of new records (Figure 7.A), indicating that high probability to discover new additional species if more sampling be conducted (BadliSham 2018). The estimation of species richness was also measured using non-parametric estimators, such as firstJack1, Jack2, Chao2, and ICE. The graph curves of all estimators lied outside the $95 \%$ confidence interval of the observed species $\left(\mathrm{S}_{\mathrm{est}}\right)$ and overestimated the species richness with a total of 282 to 436 species are expected to be found in Gunung Ledang (Figure 8). The presence of many unique and duplicate species in the assemblages could influence the performance of the estimators that leads to higher number of species estimation (Figure 7.B) (Ahmad-Zaini 2017). The unique species only occurred in one sample, while duplicate occurred in two samples (Foggo et al. 2003). Thus, it is presumed that more samples are needed to reach an asymptote and sampling completeness.

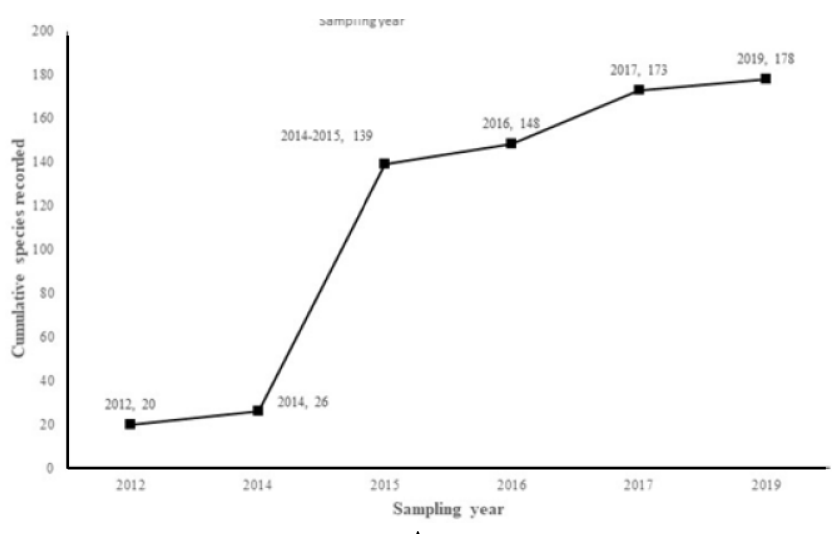

A

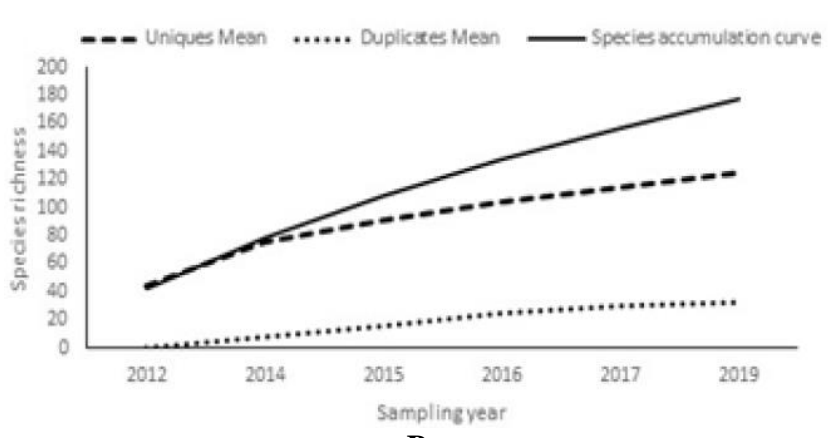

B

Figure 7. The cumulative graph of butterfly species recorded in Gunung Ledang and its vicinity from 2012 to 2019 (A) and graph of species accumulation curve and estimation of unique and duplicate species (B)

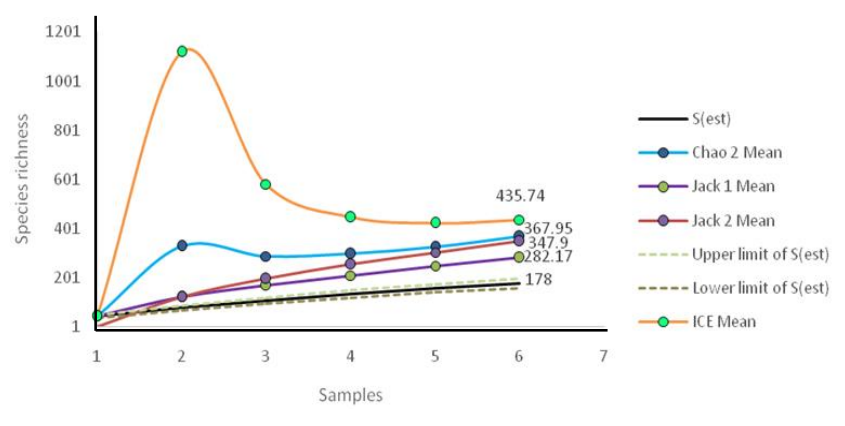

Figure 8. Observed species and species richness estimation using non-parametric estimators

In conclusion, though this short survey could not justify the actual diversity of butterflies in BRK, BB, and BT, this report presents an empirical and baseline survey of the butterfly fauna in those three hills to facilitate the authorities for the conservation and better management actions of the proposed areas. Moreover, the records of protected and rare species during this survey could justify the need to put more effort in conserving these hills. In a way to protect the butterfly communities especially these significant species from any further forest fragmentation and disturbance. In fact, the curve of species accumulation graph reported is far to level off, suggesting more butterfly species has yet been to be discovered. Thus, intensive sampling efforts in term sampling period, areas and methods are recommended for further rapid biodiversity assessment of the areas.

\section{ACKNOWLEDGEMENTS}

We would like to express our gratitude to Universiti Tun Hussein Onn Malaysia for providing contract grants (K001 and H348) and transportation to support the authors' participation in this expedition. Also, great appreciation to Johor National Park Corporation, Gunung Ledang branch for the accommodation and facilities during our participation in this expedition. Finally special thanks to all local guides especially $\mathbf{J}$ Mexrin bin Jengkeng, Fire and Rescue Department of Malaysia, Tangkak (BOMBA), Malaysia Civil Defense Force, Tangkak (APM) and friends from CoR-SUNR namely Muhammad Shafiq Hamdin, Noramira Mohd Subadi, Nouril Ammin Othman, Baizul Hafsyam Badli Sham, Muhammad Zulhusni Zakaria, Ayu Kalsom, Arney Sapaat and Muhammad Taufik Awang for their kind assistance in helping us to assure our safety during the sampling and complete the data analysis.

\section{REFERENCES}

Abang F, Fauzi N. 2004. Butterflies of Gunung Pueh-Berumput ridge. Serangga 9: 139-148.

Abu Zarim NAS, Ahmad A. 2014. Checklist of butterfly fauna at Kuala Lompat, Krau Wildlife Reserve, Pahang, Malaysia. J Wildlife Parks 28: 63-72. 
Ahmad-Zaini MIH. 2017. Assessing Species Richness and Diversity of Odonata in Sekayu Lowland Forest, Terengganu. [Dissertation] Universiti Malaysia Terengganu, Terengganu. [Malaysia]

Aqilah AAR, Maryati M, Linatoc AC. 2018. Butterfly (Lepidoptera: Rhopalocera) diversity in Bukit Soga, the green lung of Batu Pahat, Malaysia. AIP Conf Proc 2002: 020005-1-11. DOI: 10.1063/1.5050101.

Aqilah AAR. 2019. Prioritization of Conservation Areas using Species Distribution Modeling based on Current Data of Butterflies in Johor. [Dissertation]. Universiti Tun Hussein Onn Malaysia, Johor. [Malaysia]

Aris NAZ, Zakaria N, Arumugam N. 2017. Diversity of Lepidoptera at R.E.A.C.H Biod Centre, Cameron Highlands, Malaysia. J Wildlife Parks 32: 41-55

Badli-Sham BH. 2018. Spatial Ecology of Anuran Amphibian at Sekayu Lowland Forests, Terengganu, Malaysia, with Remarks on the Distribution of the Peninsular Malaysian Frog Fauna. [Dissertation]. Universiti Malaysia Terengganu, Terengganu. [Malaysia]

BERNAMA 2016. Tadahan air di Tangkak cadang diwarta Taman Negara. https: //www.bhplus.com.my/node/131880

Bonebrake TC, Pickett EJ, Tsang TPN, Tak CY, Vu MQ, Vu LV. 2016. Warming threat compounds habitat degradation impacts on a tropical butterfly community in Vietnam. Global Ecol Conserv 8: 203-211.

ButterflyCircle. 2019. Life History of the Psyche. http://butterflycircle.blogspot.my/2011/02/life-history-of-psyche.html [August 25, 2019]

Cleary DFR, Boyle TJB, Setyawati T, Menken SBJ. 2005. The impact of logging on the abundance, species richness and community composition of butterfly guilds in Borneo. JEN 129: 52-59.

Corbet A, Pendlebury H. 1992. The Butterflies of Malay Peninsula. 4th ed. Malayan Nature Society, Kuala Lumpur.

Eliot J, Kirton L. 2000. The revisional notes and nomenclatural changes of some Peninsular Malaysia butterflies. Malayan Nat J 54: 131-145.

Elith J, Phillips SJ, Hastie T, Dudik M, Chee YE, Yates CJ. 2011. A statistical explanation of MaxEnt for ecologists. Diver Distrib 17: 43 57.

Foggo A, Rundle SD, Bilton DT. 2003. The net result: evaluating species richness extrapolation techniques for littoral pond invertebrates. Freshw Biol 48: 1756-1764.

Fleming W. 1975. Butterflies of West Malaysia and Singapore. Longman Malaysia, Kuala Lumpur.

Gerlach J, Samways M, Pryke J. 2013. Terrestrial invertebrates as bioindicators: an overview of available taxonomic groups. J Insect Conserv 17: 831-850.

Ghazali N, Jauhari MAA , Sulaiman N. 2018. An updated checklist of butterflies (Lepidoptera: Rhopalocera) from Fraser's Hill, Pahang, Malaysia. Serangga 23: 143-154.

Gopal B. 2015. Guidelines for Rapid Assessment of Biodiversity and Ecosystem Services of Wetlands. National Institute of Ecology, New Delhi.

Hamer K, Hill J, Mustaffa N, Benedick S, Sherratt T, Chey V, Maryati M. 2005. Temporal variation in abundance and diversity of butterflies in Bornean rain forests: opposite impacts of logging recorded in different seasons. J Trop Ecol 21: 417-425.

Hazebroek HP, Morshidi ABA. 2006. National Parks of Sarawak. Natura History Publications, Kota Kinabalu.

Hill J, Hamer K, Dawood M, Tangah J, Chey V. 2003. Rainfall but not selective logging affect changes in abundance of a tropical forest butterfly in Sabah, Borneo. J Trop Ecol 19: 35-42.

Ismail N, Maryati M, Phon CK, Tokiman L. 2018. Spatial distribution of butterfly (Lepidoptera: Papilionoidea) in Taman Negara Johor Endau Rompin (Peta), Mersing, Johor, Malaysia. J Sci Technol 10: 17-21.

Ismail N, Maryati M, Phon CK, Tokiman L. 2018. Spatial distribution of butterfly (Lepidoptera: Papilionoidea) along altitudinal gradients at Gunung Ledang National Park, Johor, Malaysia. AIP Conf Proc 2002 020047-1-10. DOI: 10.1063/1.5050143.

Joshi PC, Arya M. 2007. Butterfly communities along altitudinal gradients in a protected forest in the Western Himalayas, India. Nat Hist J Chulalongkorn Univ 7: 1-9.

Jutta M, Chew KL. Saw LG. 2010. A new species of Cycas (Cycadaceae) from Peninsular Malaysia. Blumea 55: 249-252.

Kiew R, Lau KH. 2019. Senyumia granitica (Gesneriaceae) from Johor, Malaysia, the second species of Senyumia. PhytoKeys 117: 37-44.

Kirton L, Kirton C, Tan M. 1990. Butterflies of Kuala Tahan and Gunung Tahan in Taman Negara. J Wildlife Parks 10: 62-77.
Kirton L. 2014. A Naturalist's Guide to the Butterflies of Peninsular Malaysia, Singapore and Thailand. John Beaufoy Publishing, Oxford.

Kyerematen R, Adu-Acheampong S, Acquah-Lamptey D, Anderson RS, Owusu EH, Mantey J. 2018. Butterfly diversity: an indicator for environmental health within Tarkwa Gold Mine, Ghana. Environ Nat Resour Res 8: 69-83.

Lau KH, Saw LG. 2010. The southernmost location of Livistona speciosa in Peninsular Malaysia. In Lee SS, Kirton L, Chua L, Saw LG (eds) Conservation Malaysia Bulletin. Forest Research Institute Malaysia, Selangor.

Lau KH, Sabari D, Ramli MH, Amli N, Kanit A. 2017. Conserving the hills of Reban Kambing, Belading and Tukau: a floristic approach. Seminar Warisan Semulajadi Johor 2017, M Suite Hotel Johor Bahru, Johor Malaysia, 13014 March 2017.

Li WW, Shen HY, David CL, Yu FH. 2010. Elucidating genetic signatures of native and introduced populations of the Cycad Blue, Chilades pandava to Taiwan: a threat both to Sago palm and to native Cycas populations worldwide. Biol Invasions 12 (8): 2649-2669.

Lien VV, Yuan D. 2003. The differences of butterfly (Lepidoptera, Papilionoidea) communities in habitats with various degrees of disturbance and altitudes in tropical forests of Vietnam. Biodiv Conserv 12: 1099-1111

Madun A, Zainal Abidin MH, Baharudin MFT. 2017. Geological mapping at Bukit Belading, Bukit Tukau and Bukit Reban Kambing at Ledang district. Seminar Warisan Semulajadi Johor 2017, M Suite Hotel Johor Bahru, Johor Malaysia, 13014 March 2017.

Magurran AE. 2004. Measuring Biological Diversity. Blackwell Publishing, Oxford.

Magurran AE, Henderson P. 2011. Commonness and rarity. In: Magurran AE, McGill B (eds) Biological Diversity Frontiers in Measurement and Assessment. Oxford University Press, New York.

Magurran AE, McGill B. 2011. Biological Diversity Frontiers in Measurement and Assessment. Oxford University Press, New York

Maryati M, David MC, Mohd-Razali NA , Ahmad-Rajini F. 2014. Inventory of insects groups in Gunung Ledang, Johor, Malaysia. Serangga 19: 1-29.

Mattila N, Kaitala V, Komonen A, Paivinen J, Kotiaho J. 2011. Ecological correlates of distribution change and range shift in butterflies. Insect Conserv Divers 4: 239-246.

Nkongolo NV, Bapeamoni F. 2018. The effect of land use type on butterfly diversity at Masako Forest Reserve, Kisangani, Democratic Republic of Congo.

Mohd Taher T, Lihan T, Mustapha MA, Nor MS. 2018. Habitat selection of Tragulus napu and Tragulus javanicus using MaxEnt analysis. AIP Conference Proceedings 1940: 020058. DOI: 10.1063/1.5027973.

Pang S, Sayok A, Jenang M. 2016. Diversity of butterflies on Gunung Serambu, Sarawak, Malaysia. In: Das I, Tuen A (eds) Tropics in Biodiversity and Conservation: Naturalists, Explorers and Field Scientists in South-East Asia and Australia. Springer International Publishing, Switzerland.

Phillips S, Anderson RP, Schapire RE. 2006. Maximum entropy modeling of species geographic distributions. Ecol Modell 190: 231-259.

Ramesh T, Hussain KJ, Satpathy KK, Selvanayagam M. 2013. Seasonal population dynamics and migration of butterflies in coastal plains of Kalpakkam, southern India. In: Gupta VK, Verma AK (eds) Animal Diversity Natural History and Conservation. M/S Daya Publishing House, New Delhi.

Scriven SA, Beale CM, Benedick S, Hill JK. 2017. Barriers to dispersal of rain forest butterflies in tropical agricultural landscapes. Biotropica 49: 206-216.

Siddiki A. 2015. Insect Diversity and Composition during the Wet and Dry Seasons in Three Forest Types in Johor, Malaysia. [Dissertation]. Universiti Tun Hussein Onn Malaysia, Johor. [Malaysia].

Sulaiman N, Mohd-Nafi MN, Ishak SM, Abdullah M. 2009. Butterfly fauna (Lepidoptera: Rhopalocera) of Panti Forest Reserve. In: Razani U, Koh HL, Abdul-Rahman, Yahya M, Mohd-Rahim R, Norhayati A, Latiff A (eds) Kepelbagaian Biologi Hutan Simpan Panti, Johor: Pengurusan, Persekitaran Fizikal, Biologi dan Sosio-ekonomi. Jabatan Perhutanan Semenanjung Malaysia, Kuala Lumpur.

Sulaiman N, Tahir AM, Abdullah M. 2011. Butterfly (Lepidoptera: Rhopalocera) fauna of Imbak Canyon Conservation Area, with special reference to Gunung Kuli Base Camp. In: Latiff A, Sinun W (eds) Imbak Canyon Conservation Area, Sabah: Geology, Biodiversity and Socioeconomic Environment. Akademi Sains Malaysia, Kuala Lumpur. 
Vu LV, Vu CQ. 2011. Diversity pattern of butterfly communities (Lepidoptera, Papilionoidea) in different habitat types in a tropical rain forest of southern Vietnam. ISRN Zoology 2011: 818545, DOI: $10.5402 / 2011 / 818545$

Vu LV. 2009. Diversity and similarity of butterfly communities in five different habitat types at Tam Dao National Park, Vietnam. J Zool 277: 15-22.

Widhiono I. 2015. Diversity of butterflies in four different forest types in Mount Slamet, Central Java, Indonesia. Biodiversitas 16: 196-204.
Wildlife Conservation Act. 2010. Laws of Malaysia Act 716. Percetakan Nasional Malaysia Berhad, Kuala Lumpur.

Zaidi M, Azman S, Norela S, Poh L. 2005. Butterfly (Lepidoptera: Rhopalocera) fauna of Gunung Stong Forest Reserve. In: MohamadIsmail S, Taha D, Shafie A, Md-Som J, Faridah-Hanum I, Latiff A (eds) Taman Negeri Gunung Stong, Kelantan: Pengurusan, Persekitaran Fizikal, Biologi dan Sosio-ekonomi. Jabatan Perhutanan Semenanjung Malaysia, Kuala Lumpur. 
Table S1. The species list collected in three forest hills during this study and also a compilation of butterflies' checklist recorded in Gunung Ledang and its vicinity from 2012 to 2019. The list is arranged according to incidence data ( $1=$ presence; $0=$ absence). The abbreviations for localities: BRK = Bukit Reban Kambing; BB = Bukit Belading; BT = Bukit Tukau; TNJGL = Taman Negara Johor Gunung Ledang and GLR= Gunung Ledang Resort.

\begin{tabular}{|c|c|c|c|c|c|c|c|}
\hline Species name & 2012 & 2014 & $\begin{array}{c}2014- \\
2015\end{array}$ & 2016 & 2017 & 2019 & Localities \\
\hline \multicolumn{8}{|l|}{ Papilionidae } \\
\hline Chilasa clytia clytia (Linnaeus, 1758) & 0 & 0 & 0 & 0 & 1 & 0 & GLR \\
\hline Graphium agamemnon agamemnon (Linnaeus, 1758) & 0 & 0 & 1 & 0 & 1 & 1 & TNJGL, GLR \\
\hline Graphium eurypylus mecisteus (Distant, 1885) & 0 & 0 & 0 & 0 & 1 & 0 & GLR \\
\hline Graphium evemon eventus (Fruhstorfer, [1908]) & 0 & 0 & 0 & 0 & 1 & 0 & GLR \\
\hline Graphium sarpedon luctatius (Fruhstorfer, 1907) & 0 & 0 & 1 & 0 & 0 & 1 & TNJGL, GLR \\
\hline Papilio demoleus malayanus Wallace, 1865 & 0 & 0 & 0 & 0 & 0 & 1 & GLR \\
\hline Pachliopta neptunus neptunus (Guerin-Meneville, 1840) & 1 & 0 & 0 & 0 & 0 & 0 & TNJGL \\
\hline Papilio nephelus sunatus Corbet, 1940 & 0 & 0 & 0 & 0 & 0 & 1 & GLR \\
\hline Papilio helenus helenus Linnaeus, 1758 & 0 & 0 & 1 & 0 & 1 & 1 & TNJGL, GLR \\
\hline Papilio iswara iswara White, 1842 & 1 & 0 & 1 & 1 & 0 & 0 & TNJGL, BRK, BB, BT \\
\hline Papilio iswaroides curtisi Jordan, 1909 & 0 & 0 & 0 & 0 & 1 & 0 & GLR \\
\hline Papilio memnon agenor Linnaeus, 1758 & 1 & 0 & 0 & 0 & 1 & 1 & TNJGL, GLR \\
\hline Papilio palinurus palinurus Fabricius, 1787 & 1 & 0 & 0 & 0 & 0 & 0 & TNJGL \\
\hline Papilio polytes romulus Cramer, [1775] & 1 & 0 & 1 & 0 & 1 & 1 & TNJGL, GLR \\
\hline Pathysa antiphates itamputi (Butler, 1885) & 0 & 0 & 1 & 0 & 0 & 0 & TNJGL \\
\hline Pathysa delessertii delessertii (Guérin-Méneville, 1839) & 0 & 0 & 1 & 0 & 0 & 0 & TNJGL \\
\hline Pathysa macareus perakensis (Fruhstorfer, 1899) & 0 & 0 & 1 & 0 & 0 & 0 & TNJGL \\
\hline \multicolumn{8}{|l|}{ Pieridae } \\
\hline Appias indra plana Butler, [1879] & 0 & 0 & 1 & 0 & 0 & 0 & TNJGL \\
\hline Appias libythea olferna Swinhoe, 1890 & 0 & 0 & 1 & 0 & 0 & 1 & TNJGL, GLR \\
\hline Catopsilia pomona pomona (Fabricius, 1775) & 0 & 0 & 1 & 1 & 0 & 0 & TNJGL, BRK \\
\hline Delias hyparete metarete Butler, [1879] & 0 & 0 & 1 & 1 & 0 & 0 & TNJGL, BRK, BB, BT \\
\hline Delias ninus ninus (Wallace, 1867) & 0 & 1 & 1 & 0 & 0 & 0 & TNJGL \\
\hline Eurema ada iona Talbot, 1939 & 0 & 0 & 0 & 0 & 1 & 0 & GLR \\
\hline Eurema andersonii andersonii (Moore, 1886) & 0 & 0 & 1 & 0 & 0 & 0 & TNJGL \\
\hline Eurema hecabe contubernalis (Moore, 1886) & 1 & 0 & 1 & 1 & 1 & 0 & TNJGL, BRK, GLR \\
\hline Eurema lacteola lacteola (Distant, 1886) & 0 & 0 & 1 & 0 & 0 & 0 & TNJGL \\
\hline Eurema sari sodalis (Moore, 1886) & 0 & 0 & 1 & 0 & 0 & 0 & TNJGL \\
\hline Eurema simulatrix tecmessa (de Nicéville, [1896]) & 0 & 0 & 1 & 0 & 0 & 0 & TNJGL \\
\hline Leptosia nina nina (Fabricius, 1793) & 1 & 0 & 1 & 1 & 1 & 0 & TNJGL, BRK, GLR \\
\hline \multicolumn{8}{|l|}{ Nymphalidae } \\
\hline Danaus melanippus hegesippus (Cramer, [1777]) & 0 & 0 & 1 & 0 & 0 & 0 & TNJGL \\
\hline Euploea doubledayi evalida (Swinhoe, 1899) & 0 & 0 & 1 & 0 & 0 & 0 & TNJGL \\
\hline Euploea eunice leucogonis (Butler, [1879]) & 0 & 0 & 1 & 0 & 0 & 0 & TNJGL \\
\hline Euploea mulciber mulciber (Cramer, [1777]) & 0 & 0 & 1 & 0 & 1 & 0 & TNJGL, GLR \\
\hline Euploea sylvester harrisii C. \& R. Felder, [1865] & 0 & 0 & 0 & 1 & 0 & 0 & BT \\
\hline Euploea radamanthus radamanthus(Fabricius, 1793) & 0 & 0 & 1 & 0 & 1 & 1 & TNJGL, GLR \\
\hline Euploea tulliolus ledereri C. \& R. Felder, 1860 & 0 & 0 & 1 & 0 & 0 & 0 & TNJGL \\
\hline Idea hypermnestra linteata (Butler, [1879]) & 0 & 0 & 1 & 0 & 0 & 1 & TNJGL, GLR \\
\hline Idea stolli logani (Moore, 1883) & 0 & 0 & 1 & 0 & 0 & 0 & TNJGL \\
\hline Ideopsis gaura perakana Fruhstorfer, [1899] & 0 & 1 & 1 & 1 & 0 & 0 & TNJGL, BB \\
\hline Ideopsis vulgaris macrina (Fruhstorfer, 1904) & 0 & 0 & 1 & 0 & 0 & 0 & TNJGL \\
\hline Parantica aspasia aspasia (Fabricius, 1787) & 0 & 1 & 1 & 0 & 0 & 0 & TNJGL \\
\hline Parantica melaneus sinopion Fruhstorfer, 1910 & 0 & 1 & 0 & 0 & 0 & 0 & TNJGL \\
\hline Elymnias casiphone saueri Distant, 1882 & 0 & 0 & 1 & 0 & 1 & 1 & TNJGL, GLR \\
\hline Elymnias hypermnestra tinctoria Moore, [1879] & 0 & 0 & 1 & 1 & 0 & 0 & TNJGL, BT \\
\hline Elymnias panthera panthera (Fabricius, 1787) & 0 & 0 & 1 & 0 & 0 & 1 & TNJGL, GLR \\
\hline Elymnias penanga penanga (Westwood, [1851]) & 0 & 0 & 1 & 0 & 0 & 1 & TNJGL, GLR \\
\hline Mycalesis fusca fusca (C. \& R. Felder, 1860) & 0 & 0 & 1 & 0 & 0 & 0 & TNJGL \\
\hline Mycalesis intermedia distanti (Moore, [1892]) & 0 & 0 & 1 & 0 & 0 & 1 & TNJGL, GLR \\
\hline Mycalesis maianeas maianeas Hewitson, [1864] & 0 & 0 & 1 & 0 & 0 & 0 & TNJGL \\
\hline Mycalesis mineus marcomalayana Fruhstorfer, 1911 & 0 & 0 & 1 & 0 & 0 & 0 & TNJGL \\
\hline Mycalesis oroatis ustulata Distant 1885 & 0 & 0 & 1 & 0 & 0 & 0 & TNJGL \\
\hline Mycalesis orseis nautilus Butler, 1867 & 0 & 0 & 1 & 0 & 1 & 1 & TNJGL, GLR \\
\hline Mycalesis perseoides perseoides (Moore, [1892]) & 0 & 0 & 1 & 0 & 0 & 1 & TNJGL, GLR \\
\hline Mycalesis perseus cepheus Butler, 1867 & 0 & 0 & 1 & 0 & 0 & 0 & TNJGL \\
\hline Mycalesis visala phamis Talbot \& Corbet, 1939 & 0 & 0 & 1 & 0 & 0 & 0 & TNJGL \\
\hline
\end{tabular}




\begin{tabular}{|c|c|c|c|c|c|c|c|}
\hline Ragadia makuta siponta Fruhstorfer, 1911 & 0 & 0 & 1 & 0 & 0 & 0 & TNJGL \\
\hline Ypthima baldus newboldi Distant, 1882 & 0 & 0 & 0 & 1 & 0 & 0 & BRK \\
\hline Ypthima fasciata toraneFruhstorfer, 1911 & 0 & 0 & 0 & 0 & 1 & 0 & BT \\
\hline Ypthima horsfieldii humei Elwes \& Edwards, 1893 & 0 & 0 & 1 & 1 & 0 & 0 & TNJGL \\
\hline Ypthima pandocus corticaria Butler, [1879]/ & 0 & 1 & 1 & 0 & 0 & 0 & TNJGL \\
\hline \multicolumn{8}{|l|}{ Y. pandocus tahanensis Pendlebury, 1933} \\
\hline Amathusia binghami Fruhstorfer, 1904 & 0 & 0 & 0 & 0 & 0 & 1 & GLR \\
\hline Amathusia phidippus phidippus (Linnaeus, 1763) & 0 & 0 & 0 & 0 & 1 & 1 & GLR \\
\hline Amathusia ochraceofusca ochraceofusca Honrath, [1888] & 0 & 0 & 1 & 0 & 1 & 0 & TNJGL, GLR \\
\hline Amathuxidia amythaon dilucida (Honrath, 1884) & 0 & 0 & 1 & 0 & 0 & 0 & TNJGL \\
\hline Faunis canens arcesilas Stichel, 1933 & 0 & 0 & 1 & 0 & 0 & 0 & TNJGL \\
\hline Zeuxidia amethystus amethystus Butler, 1865 & 0 & 0 & 1 & 0 & 1 & 0 & TNJGL, GLR \\
\hline Zeuxidia doubledayi doubledayi Westwood, [1851] & 0 & 0 & 1 & 0 & 1 & 1 & TNJGL, GLR \\
\hline Athyma abiasa clerica Butler, [1879] & 0 & 0 & 1 & 0 & 0 & 0 & TNJGL \\
\hline Athyma nefte subrata Moore, 1858 & 1 & 0 & 0 & 0 & 1 & 0 & TNJGL \\
\hline Bassarona teuta rayana (Morishita, 1968)/ & 0 & 0 & 0 & 0 & 1 & 1 & TNJGL, GLR \\
\hline \multicolumn{8}{|l|}{ B. teuta goodrichi (Distant, 1886) } \\
\hline Cethosia hypsea hypsina C. \& R. Felder, [1867] & 0 & 0 & 1 & 0 & 0 & 0 & TNJGL \\
\hline Chersonesia intermedia intermedia Martin, 1895 & 0 & 0 & 1 & 0 & 0 & 0 & TNJGL \\
\hline Chersonesia rahria rahria (Moore, [1858]) & 0 & 0 & 1 & 0 & 1 & 0 & TNJGL \\
\hline Cirrochroa emalea emalea (Guerin-Meneville, 1843) & 1 & 0 & 0 & 0 & 0 & 0 & TNJGL \\
\hline Cirrochroa malaya malaya C. \& R. Felder, 1860 & 0 & 0 & 1 & 0 & 0 & 0 & TNJGL \\
\hline Cirrochroa orissa orissa C. \& R. Felder, 1860 & 1 & 0 & 1 & 0 & 0 & 0 & TNJGL \\
\hline Coelites epiminthia epiminthia Westwood, [1851] & 0 & 0 & 0 & 0 & 1 & 0 & GLR \\
\hline Cupha erymanthis lotis (Sulzer, 1776) & 0 & 0 & 1 & 1 & 1 & 0 & TNJGL, BRK. GLR \\
\hline Cyrestis cocles earli Distant, 1883 & 0 & 0 & 1 & 1 & 1 & 0 & TNJGL, BRK, BT, GLR \\
\hline Cyrestis nivea nivalis C. \& R. Felder, [1867] & 0 & 0 & 1 & 0 & 0 & 0 & TNJGL \\
\hline Cyrestis themire themire Honrath, [1884] & 0 & 0 & 1 & 0 & 0 & 0 & TNJGL \\
\hline Discophora necho engamon Fruhstorfer, 1911 & 0 & 0 & 0 & 0 & 1 & 0 & GLR \\
\hline Dophla evelina compta Fruhstorfer, 1899 & 0 & 0 & 1 & 0 & 1 & 1 & TNJGL, GLR \\
\hline Eulacera osteria kumana Fruhstorfer, 1913 & 0 & 0 & 1 & 0 & 0 & 0 & TNJGL \\
\hline Euthalia alpheda langkawica Eliot, 1980 & 0 & 0 & 1 & 0 & 0 & 0 & TNJGL \\
\hline Euthalia eriphylae de Nicéville, 1891 & 0 & 0 & 1 & 0 & 0 & 0 & TNJGL \\
\hline Euthalia ipona Fruhstorfer, 1913 & 0 & 0 & 1 & 0 & 0 & 0 & TNJGL \\
\hline Euthalia kanda marana Corbet, 1937 & 0 & 0 & 1 & 0 & 0 & 0 & TNJGL \\
\hline Euthalia monina monina (Fabricius, 1787) & 0 & 0 & 1 & 0 & 0 & 0 & TNJGL \\
\hline Hypolimnas bolina bolina (Linnaeus, 1758)/ & 0 & 0 & 1 & 0 & 1 & 0 & TNJGL, BRK, BT \\
\hline \multicolumn{8}{|l|}{ H. bolina jacintha (Drury, 1773) } \\
\hline Junonia hedonia ida (Cramer, [1775]) & 0 & 0 & 1 & 0 & 1 & 0 & TNJGL, GLR \\
\hline Junonia orithya wallacei Distant, 1883 & 0 & 0 & 0 & 1 & 0 & 0 & BRK \\
\hline Lasippa tiga siaka (Moore, 1881) & 0 & 0 & 1 & 0 & 0 & 0 & TNJGL \\
\hline Lebadea martha malayana Fruhstorfer, [1902] & 0 & 0 & 1 & 0 & 1 & 0 & TNJGL, GLR \\
\hline Lethe mekara gopakaFruhstorfer, 1911 & 0 & 0 & 0 & 0 & 0 & 1 & GLR \\
\hline Lexias canescens pardalina(Staudinger, 1886) & 0 & 0 & 0 & 0 & 1 & 0 & GLR \\
\hline Lexias dirtea merguia (Tytler, 1926) & 1 & 0 & 0 & 0 & 0 & 0 & TNJGL \\
\hline Lexias pardalis dirteana (Corbet, 1941) & 1 & 0 & 1 & 0 & 1 & 0 & TNJGL, GLR \\
\hline Moduza procris milonia (Fruhstorfer, 1906) & 0 & 0 & 1 & 0 & 0 & 0 & TNJGL \\
\hline Neorina lowii neophyta Fruhstorfer, 1911 & 0 & 0 & 0 & 0 & 1 & 0 & GLR \\
\hline Neptis harita harita Moore, [1875] & 0 & 0 & 1 & 0 & 0 & 0 & TNJGL \\
\hline Neptis leucoporos cresina Fruhstorfer, 1908 & 0 & 0 & 1 & 0 & 0 & 0 & TNJGL \\
\hline Neptis miah batara Moore, 1881 & 0 & 0 & 1 & 0 & 0 & 0 & TNJGL \\
\hline Neptis soma pendleburyi Corbet, 1937 & 0 & 0 & 1 & 0 & 0 & 0 & TNJGL \\
\hline Phaedyma columella singa (Fruhstorfer, 1899) & 0 & 0 & 0 & 0 & 1 & 0 & GLR \\
\hline Phalanta alcippe alcesta Corbet, 1941 & 0 & 0 & 1 & 0 & 0 & 0 & TNJGL \\
\hline Polyura hebe chersonesus (Fruhstorfer, 1898) & 0 & 0 & 0 & 0 & 1 & 0 & GLR \\
\hline Rhinopalpa polynice eudoxia (Guérin-Méneville, 1840) & 0 & 0 & 1 & 0 & 0 & 0 & TNJGL \\
\hline Tanaecia aruna aruna (C. \& R. Felder, 1860) & 0 & 0 & 1 & 0 & 1 & 0 & TNJGL, GLR \\
\hline Tanaecia flora andersonii Moore, 1884 & 0 & 0 & 1 & 0 & 0 & 0 & TNJGL \\
\hline Tanaecia godartii asoka (C. \& R. Felder, [1867]) & 0 & 0 & 1 & 0 & 0 & 0 & TNJGL \\
\hline Tanaecia iapis puseda (Moore, [1858]) & 0 & 0 & 1 & 0 & 0 & 0 & TNJGL \\
\hline Tanaecia palguna consanguinea Distant, 1886 & 0 & 0 & 1 & 1 & 0 & 0 & TNJGL, BRK \\
\hline Terinos atlita teuthras Hewitson, 1862 & 0 & 0 & 1 & 0 & 0 & 0 & TNJGL \\
\hline Terinos clarissa malayanus Fruhstorfer, 1906 & 0 & 0 & 1 & 0 & 0 & 0 & TNJGL \\
\hline Terinos terpander robertsia Butler, 1867 & 0 & 0 & 1 & 0 & 1 & 1 & TNJGL, GLR \\
\hline Vagrans egista macromalayana (Fruhstorfer, 1912) & 0 & 0 & 1 & 0 & 0 & 0 & TNJGL \\
\hline Vindula dejone erotella (Butler, [1879]) & 0 & 0 & 1 & 0 & 0 & 0 & TNJGL \\
\hline Agatasa calydonia calydonia (Hewitson, [1854]) & 1 & 0 & 1 & 0 & 1 & 0 & TNJGL, GLR \\
\hline
\end{tabular}




\begin{tabular}{llllllll}
\hline Charaxes bernardus crepax Fruhstorfer, 1913 & 0 & 0 & 0 & 1 & 0 & 0 & BRK, BT \\
$\quad$ Charaxes durnfordi durnfordi Distant, 1884 & 1 & 0 & 1 & 1 & 0 & 1 & TNJGL, BRK, GLR \\
Prothoe franck uniformis Butler, 1885 & 0 & 0 & 1 & 0 & 0 & 0 & TNJGL \\
& & & & & & & \\
Riodinidae & & & & & & & \\
Abisara kausambi kausambi C. \& R. Felder, 1860 & 0 & 0 & 1 & 0 & 0 & 0 & TNJGL \\
Abisara geza niya Fruhstorfer, 1914 & 0 & 0 & 1 & 0 & 0 & 0 & TNJGL \\
Abisara savitri savitri C. \& R. Felder, 1860 & 0 & 0 & 0 & 0 & 0 & 1 & GLR \\
Laxita thuisto thuisto (Hewitsonn, [1861]) & 0 & 0 & 1 & 0 & 0 & 0 & TNJGL \\
Paralaxita damajanti damajanti (C. \& R. Felder, 1860) & 0 & 0 & 1 & 0 & 0 & 0 & TNJGL \\
Paralaxita orphna laocoon (de Niceville, 1894) & 1 & 0 & 0 & 0 & 0 & 0 & TNJGL \\
Taxila haquinus haquinus (Fabricius, 1793) & 0 & 0 & 1 & 0 & 1 & 1 & TNJGL, GLR \\
Zemeros emesoides emesoides C. \& R. Felder, 1860 & 1 & 0 & 1 & 0 & 0 & 0 & TNJGL
\end{tabular}

\section{Lycaenidae}

Allotinus horsfieldi permagnusFruhstorfer, 1913 Allotinus unicolor unicolor C. \& R. Felder, [1865] Arhopala athada athada (Staudinger, 1889) Arhopala azinis azinis de Niceville, [1896] Arhopala abseus abseus (Hewitson, 1862) Arhopala achelous achelous (Hewitson, 1862) Arhopala hypomuta hypomuta (Hewitson, 1862) Arhopala metamuta metamuta (Hewitson, [1863]) Arhopala phaenops sandakani Bethune-Baker, 1896 Chilades pandava pandava (Horsfield, [1829]) Deramas nolens pasteuri Eliot, 1978 Drupadia ravindra moorei (Distant, 1882) Drupadia theda thesmia (Hewitson, [1863]) Eooxylides tharis distanti Riley, 1942 Hypolycaena amabilis lisba (Corbet, 1948) Jamides alecto ageladas (Fruhstorfer, 1915) Jamides bochus nabonassar (Fruhstorfer, 1915) Jamides ferrari evansi Riley \& Corbet, 1938 Jamides malaccanus malaccanus (Röber, 1886) Jamides pura pura (Moore, 1886)

Jamides talinga (Kheil, 1884)

Jamides virgulatus nisanca (Fruhstorfer, 1915)

Jamides zebra lakatti Corbet, 1940

Logania distanti massaliaDoherty, 1891

Megisba malaya sikkima Moore, 1884

Miletus biggsii biggsii(Distant, 1884)

Nacaduba berenice icena Fruhstorfer, 1916

Nacaduba hermus swatipa Corbet, 1938

Nacaduba kurava kurava Fruhstorfer, 1916 Neocheritra amrita amrita (C. \& R. Felder, 1860) Prosotas nora superdates (Fruhstorfer, 1916) Zizula hylax pygmaea (Snellen, 1876)

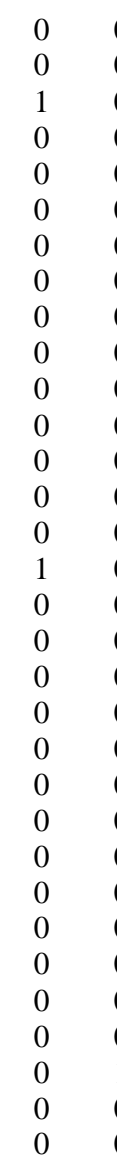

\section{Hesperiidae}

Celaenorrhinus ladana (Butler, 1870)

Eetion elia(Hewitson, [1866]

Halpe insignis (Distant, 1886)

Hasora zoma Evans, 1934

Tagiades litigiosus litigiosus (Möschler, 1878)

Gangara thyrsis thyrsis (Fabricius, 1775)

Iambrix salsala salsala (Moore, [1886])

Idmon distanti (Distant, 1886)

Koruthaialos rucubela rucubela (Plotz, 1882)

Koruthaialos sindu sindu(C. \& R. Felder, 1860)

Matapa sasivarna (Moore, [1866])

Notocrypta clavata clavata (Staudinger, 1889)

Plastingia naga (de Nicéville, [1884])

Potantus mingo ajax (Evans, 1932)

Potantus omaha omaha (W. H. Edwards, 1863)

Taractrocera archias quinta Swinhoe, [1912]

$\begin{array}{lllllll}1 & 0 & 0 & 0 & 0 & 0 & \text { TNJGL } \\ 1 & 0 & 0 & 0 & 0 & 0 & \text { TNJGL } \\ 0 & 0 & 0 & 1 & 0 & 0 & \text { BRK } \\ 0 & 0 & 1 & 0 & 0 & 0 & \text { TNJGL } \\ 0 & 0 & 1 & 0 & 0 & 0 & \text { TNJGL } \\ 0 & 0 & 1 & 0 & 0 & 0 & \text { TNJGL } \\ 0 & 0 & 0 & 1 & 1 & 0 & \text { TNJGL, BRK } \\ 0 & 0 & 1 & 0 & 0 & 0 & \text { TNJGL } \\ 0 & 0 & 0 & 0 & 1 & 0 & \text { GLR } \\ 0 & 0 & 0 & 0 & 1 & 0 & \text { GLR } \\ 0 & 0 & 1 & 0 & 0 & 0 & \text { TNJGL } \\ 0 & 0 & 1 & 0 & 0 & 0 & \text { TNJGL } \\ 0 & 0 & 0 & 1 & 0 & 0 & \text { BT } \\ 0 & 0 & 1 & 0 & 0 & 0 & \text { TNJGL } \\ 0 & 0 & 1 & 0 & 0 & 0 & \text { TNJGL } \\ 0 & 0 & 0 & 0 & 1 & 0 & \text { GLR }\end{array}$

